\title{
Blood LH Level and Induced Ovulation after hCG and PMSG Treatment in Ovarian Quiescent Cattle
}

\author{
Hideo KAMOMAE*, Yoshihiro KANEDA ${ }^{1)}$, Ikuo DOMEKI ${ }^{2)}$, and Tatsuo NAKAHARA ${ }^{3)}$ \\ Third Research Division, National Institute of Animal Health, Tsukuba, Ibaraki 305, ${ }^{1)}$ Faculty of Agriculture, Iwate \\ University, Morioka, Iwate 020, ${ }^{2)}$ Department of Animal Reproduction, National Institute of Animal Industry, \\ Ikenodai, Kukizaki, Ibaraki 305, ${ }^{3)}$ Nodai Research Institute, Tokyo University of Agriculture, Setagaya, Tokyo 156, \\ Japan
}

(Received 13 May 1988/Accepted 30 December 1988)

\begin{abstract}
Ovarian quiescent cattle bearing follicle with palpable size were treated with single intramuscular injection of 750-6,000 IU of human chorionic gonadotrophin (hCG) in 13 cases and 1,000-2,000 IU of pregnant mare serum gonadotrophin (PMSG) in 5 cases. Changes of blood luteinizing hormone (LH) level, estrus and ovulation after the treatments were examined. After the hCG treatment LH level became slightly high from $0.2-0.6 \mathrm{ng} / \mathrm{m} l$ of pre-treatment to $0.3-1.9 \mathrm{ng} / \mathrm{m} l$ of post-treatment and maintained the level up to ovulation without the ovulatory $\mathrm{LH}$ surge. Ovulation was induced about $36 \mathrm{hr}$ after the treatment in 12 cases. The ovulations were all silent ovulations. After the PMSG treatment LH level became slightly high from $0.6 \mathrm{ng} / \mathrm{m} l$ of pre-treatment to $1.3 \mathrm{ng} / \mathrm{m} l$ of post-treatment and the level lasted until the ovulatory LH surge. The ovulatory LH surge occurred about $39 \mathrm{hr}$ after the PMSG treatment in 4 cases with a peak of about $32 \mathrm{ng} / \mathrm{m} l$. Ovulation was induced about $74 \mathrm{hr}$ after the treatment in all 5 cases. Four cases showed estrus but one in which the LH surge could not be confirmed did silent estrus preceding the induced ovulations. It was demonstrated that hCG induced ovulation without the LH surge but PMSG induced the ovulatory LH surge and the subsequent ovulation in ovarian quiescent cattle.-KEY wORDS: cattle, hCG, LH, ovarian quiescence, PMSG.
\end{abstract}

Jpn. J. Vet. Sci. 51(3): 467-473, 1989

Human chorionic gonadotrophin (hCG) and pregnant mare serum gonadotrophin (PMSG) are commonly used in treatment for ovarian disorders, improving the fertility, and induction of superovulation in cattle $[5,11,15]$. The actions of these hormones had been investigated mainly in laboratory small animals $[10,14,16,17,20,21]$. Several reports have been published to demonstrate peculialities of action of and reaction to the hormones in cattle $[1-4,12$, 19], but effects on follicular growth, ovulation, corpus luteum (CL) formation and CL function are not well understood or known. The authors have been examining effects of

*Corespondence to: Kamomae H. Department of Animal Reproduction, National Institute of Animal Industry, Tsukuba Norindanchi P.O.Box 5, Ibaraki 305, Japan. the gonadotrophins and an analogue of luteinizing hormone-releasing hormone (LH-RH-A) on follicular growth, ovulation and $\mathrm{CL}$ formation in ovarian quiescent heifers [6-9]. Those results indicate that hCG acted on follicle to ovulate directly, but PMSG acted on follicle to secrete estrogen actively so that the ovulatory $\mathrm{LH}$ surge and ovulation occur subsequently.

In this report, change of blood luteinizing hormone (LH) level and ovulation following hCG and PMSG treatment were examined so as to clarify the action of the hormones inducing ovulation in ovarian quiescent cattle.

MATERIALS AND METHODS

Animals and treatments: Eleven ovarian 
quiescent cattle bearing follicle(s) with palpable size were treated with hCG (Experiment A) or PMSG (Experiment B). Ovarian quiescence were diagnosed by repeated rectal palpations and clinical examinations of ovaries and other genital organs at 1-2 days interval for at least last 9 days.

Experiment A consisted of Experiments A-1 and A-2. In Experiment A-1, 5 Holstein heifers received a single intramuscular (IM) injection of 750-3,000 IU of hCG. When the treatment did not induce the normal ovarian cyclic activity, 2nd and 3rd treatment were conducted 25-26 and 59 days after the preceding treatment with 2-4 times dosage. A total of 11 cases were attained in the 5 heifers and divided into 4 treatment groups. Every 3 cases of Group I, II and III received $750,1,500$ and 3,000 IU of hCG, respectively. Two cases of Group IV did 6,000 IU of hCG. Mean age and body weight of the cases were $18.2 \pm 2.7$ (SD) months and $337.1 \pm 21.8 \mathrm{~kg}$. In Experiment A-2, 2 Japanese Black received a single IM injection of 3,000 IU of hCG. The mean age and body weight were $9.5 \pm 4.9$ years and $291.0 \pm 96.2 \mathrm{~kg}$. The hCG preparation used was PUBEROGEN (Sankyo Co., Ltd., Tokyo).

In Experiment B, 4 Japanese Black received a single IM injection of 1,000 IU of PMSG. One of them received a 2 nd single IM injection of 2,000 IU of PMSG on 153 days after the 1 st treatment. Mean age and body weight of the cases were $8.8 \pm 4.4$ years and $288.8 \pm 70.9 \mathrm{~kg}$. The PMSG preparation used was PEAMEX (Sankyo Co., Ltd., Tokyo).

Blood sampling: Blood samples were collected via jugular venipuncture $10 \mathrm{~min}$ and just before the treatment and then at 15-60 min intervals for $8 \mathrm{hr}$ after the treatment in Experiment A-1, and 30, 10 min and just before the treatment and then at $1 \mathrm{hr}$ interval until ovulation for 33-36 hr in Experiment A-2. In Experiment B blood samples were collected in the same way as Experiment $\mathrm{A}$ just before the treatment and then $2-12 \mathrm{hr}$ intervals until ovulation for 72-84 hr. Serum or plasma were separated and stored at $-20^{\circ} \mathrm{C}$ until analyzed.

Estrus and ovulation: Standing estrus and other estrous signs were observed at 6-12 hr intervals. Occurrence of ovulation was examined by rectal palpation at 3-6 hr intervals.

Animal feeding: Five heifers used in Experiment A-1 were kept in free stall. They were fed with the concentrates and hay in the ratio of 110,120 and $105 \%$ to dry matter (DM), digestible crude protein (DCP) and total digestible nutrients (TDN) of $0.8 \mathrm{~kg}$ daily gain (DG) level of the Japanese Feeding Standard for Dairy Cattle (1987), respectively. The 2 cattle submitted to Experiment A-2 and the 2 cases of Experiment $\mathrm{B}$ were grazed in daytime and fed supplementally with $0.5 \mathrm{~kg}$ of the concentrates in a day. Other 3 cases of Experiment B were kept in stanchion stall and fed with the concentrates and hay cube in the ratio of 55,165 and $65 \%$ to DM, DCP and TDN of $0.2 \mathrm{~kg}$ DG level of the Japanese Feeding Standard for Beef Cattle (1987), respectively.

LH assay: Blood LH was quantified by double antibody radioimmunoassay method described by Niswender et al. [13] with some modification [9]. Anti-bovine LH serum (B 225) was generously supplied by Dr. G. D. Niswender. Highly purified bovine LH, i. e. LER-1072-2 and LER-1716-2 were kindly provided by Dr. L. E. Reichert and by Dr. T. Johke severally, and the former was used in Experiment A-1 and the latter was done in Experiments A-2 and B. The sensitivity, intra-assay and inter-assay coefficient of variations were $0.10 \mathrm{ng} / \mathrm{m} l, 13.0 \%$ and $20.9 \%$, respectively.

Statistical analysis: Data were analyzed by Student's $t$-test and difference was considered significant when the probavility $(\mathrm{P})$ was 
Table 1. Blood LH level, estrus and ovulation following hCG treatment in ovarian quiescent cattle (Experiment A)

\begin{tabular}{|c|c|c|c|c|c|c|c|c|c|}
\hline $\begin{array}{c}\text { Experi. } \\
\text { ment }\end{array}$ & Group & $\begin{array}{c}\mathrm{hCG} \\
\text { injected } \\
(\mathrm{IU})\end{array}$ & $\begin{array}{c}\text { No. } \\
\text { of } \\
\text { cattle }\end{array}$ & $\begin{array}{l}\text { Pre-treatment } \\
\text { LH level }{ }^{1)} \\
(\mathrm{ng} / \mathrm{m} l)\end{array}$ & $\begin{array}{l}\text { Post-treatment } \\
\text { LH level }{ }^{2)} \\
(\mathrm{ng} / \mathrm{m} l)\end{array}$ & $\begin{array}{l}\text { Highest } \\
\text { LH value }{ }^{3)} \\
(\mathrm{ng} / \mathrm{m} l)\end{array}$ & $\begin{array}{l}\text { Peak of } \\
\text { LH surge } \\
(\mathrm{ng} / \mathrm{m} l)\end{array}$ & $\begin{array}{c}\text { Occurrence } \\
\text { of estrus }\end{array}$ & $\begin{array}{l}\text { Ovulation } \\
\text { after } \\
\text { treatment }(\mathrm{hr})\end{array}$ \\
\hline \multirow[t]{5}{*}{ A-1 } & I & 750 & 3 & $0.14 \pm 0.12^{\mathrm{a})}$ & $0.15 \pm 0.15^{b)}$ & $0.66 \pm 0.33^{m)}$ & NO & NO & $39.0 \pm 4.2(\mathrm{n}=2)$ \\
\hline & II & 1,500 & 3 & $0.17 \pm 0.06$ & $0.24 \pm 0.22^{c, d)}$ & $0.72 \pm 0.61$ & NO & NO & $38.0 \pm 3.5 \quad(n=3)$ \\
\hline & III & 3,000 & 3 & $0.12 \pm 0.08$ & $0.39 \pm 0.46^{\mathrm{c}, \mathrm{e}, \mathrm{g})}$ & $1.83 \pm 0.67$ & NO & NO & $38.0 \pm 3.5 \quad(n=3)$ \\
\hline & IV & 6,000 & 2 & $0.27 \pm 0.16$ & $0.59 \pm 0.35^{\mathrm{c}, \mathrm{f}, \mathrm{h})}$ & $1.90 \pm 0.07^{\mathrm{n})}$ & NO & NO & $36.0 \pm 0 \quad(n=2)$ \\
\hline & Overal & ll mean & & $0.17 \pm 0.11^{1)}$ & $0.32 \pm 0.35^{\mathrm{j})}$ & $1.22 \pm 0.75$ & $\mathrm{NO}$ & NO & $37.8 \pm 2.9(n=10)$ \\
\hline A- -2 & & 3,000 & 2 & $0.62 \pm 0.20^{k)}$ & $1.90 \pm 0.92^{1)}$ & $2.34 \pm 1.43$ & NO & NO & $34.5 \pm 2.1 \quad(n=2)$ \\
\hline
\end{tabular}

1) Mean value of 10 and $0 \mathrm{~min}$ or 30,10 and $0 \mathrm{~min}$ before the treatment.

2) Mean value for $8 \mathrm{hr}$ after the treatment.

3) Highest value during $8 \mathrm{hr}$ after the treatment.

a) Mean $\pm \mathrm{SD}$.

NO: No occurred.

b-n) Significant differences were detected between $b$ and $c, d$ and $f, g$ and $h$; and $k$ and $l$ with $P<0.01$, and between $d$ and $e, i$ and $j$, and $\mathrm{m}$ and $\mathrm{n}$ with $\mathrm{P}<0.05$, respectively.

$<0.05$

\section{RESULTS}

Change of LH level, estrous signs and ovulation after hCG treatment were shown in Table 1. In Experiment A-1, LH level changed in low levels for $8 \mathrm{hr}$ after the treatment without the ovulatory LH surge, though the level became slightly elevated. Mean highest $\mathrm{LH}$ value during $8 \mathrm{hr}$ were $0.66,0.72,1.83$ and $1.90 \mathrm{ng} / \mathrm{m} l$ in Groups I, II, III and IV, respectively. The slight elevation of $\mathrm{LH}$ was dose responsive and the mean highest value of $\mathrm{LH}$ also seemed to become higher as the dosage increased. Ovulation was induced in 10 cases except 1 of Group I, and mean time course of ovulation were $36.0-39.0 \mathrm{hr}$ in every group. Estrous signs were unnoticeable at the ovulation, i. e. silent ovulation.

In Experiment A-2, LH level continued low up to ovulation, though slight increase of LH occurred and lasted after the treatment. Ovulation was induced mean $34.5 \mathrm{hr}$ after the treatment. Estrous signs were obscure and silent ovulation occurred.
The results obtained in Experiment $\mathrm{A}$ were shown in Fig. 1, conclusively. After hCG treatment blood LH levels lasted low up to the induced ovulation without the ovulatory LH surge.

Change of blood LH level, estrus and ovulation following PMSG treatment were shown in Table 2. In all 5 cases LH level lasted low for $30-42 \mathrm{hr}$ after the PMSG treatment, though the level became slightly elevated. And then the ovulatory LH surge occurred in 4 cases. The surge showed a high peak with $31.88 \mathrm{ng} / \mathrm{m} l$ at $39 \mathrm{hr}$ after the treatment as means. About the 4 cases, change of $\mathrm{LH}$, estrus and ovulation were shown in Fig. 2 as the time when the LH level showed a peak was reckoned to 0 . Estrus started $1.5 \mathrm{hr}$ before the $\mathrm{LH}$ peak and lasted for $22.5 \mathrm{hr}$ as means. Ovulation occurred mean $33.0 \mathrm{hr}$ after the peak of LH. In 1 case (No.145) LH level reached 3.05 and $3.10 \mathrm{ng} / \mathrm{ml}$ at $36 \mathrm{hr}$ and $48 \mathrm{hr}$ after the treatment. But the level decreased to low with $1.45 \mathrm{ng} / \mathrm{m} l$ at $54 \mathrm{hr}$ and then lasted low $(1.0-1.6 \mathrm{ng} / \mathrm{ml})$. This case showed ovulation $84 \mathrm{hr}$ after the treatment with silent estrus. 
Experiment A-1 $(n=11)$

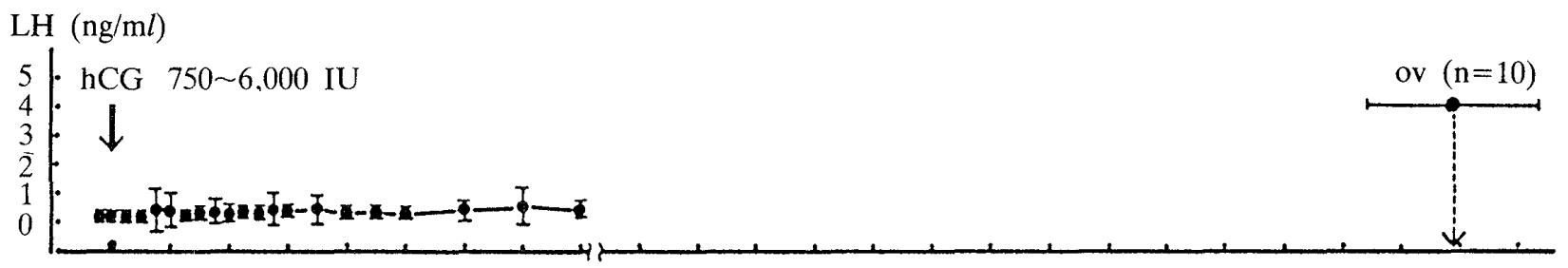

Experiment A-2 $(n=2)$

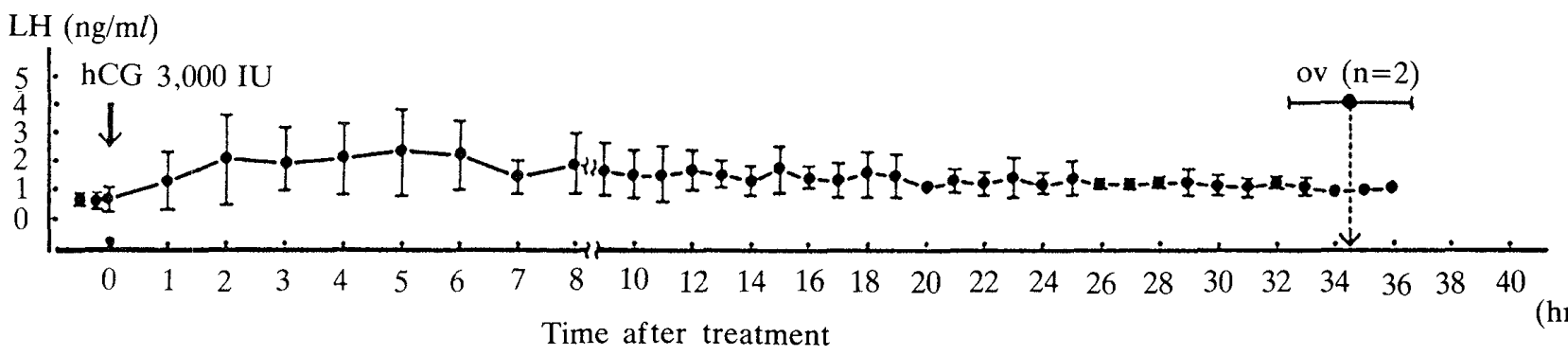

Fig. 1. Change of blood LH level following hCG treatment in ovarian quiescent cattle. $\$:$ Mean $\pm S D$, ov: Ovulation.

Table 2. Blood LH level, estrus and ovulation following PMSG treatment in ovarian quiescent cattle (Experiment B)

\begin{tabular}{|c|c|c|c|c|c|c|c|c|}
\hline \multirow[b]{2}{*}{$\begin{array}{l}\text { Cattle } \\
\text { No. }\end{array}$} & \multirow[b]{2}{*}{$\begin{array}{c}\text { PMSG } \\
\text { injected } \\
\text { (IU) }\end{array}$} & \multirow[b]{2}{*}{$\begin{array}{l}\text { Pre-treatment } \\
\text { LH level }{ }^{1)} \\
(\mathrm{ng} / \mathrm{m} l)\end{array}$} & \multirow[b]{2}{*}{$\begin{array}{l}\text { Post-treatment } \\
\text { LH level }{ }^{2)} \\
(\mathrm{ng} / \mathrm{m} l)\end{array}$} & \multicolumn{2}{|c|}{ Ovulatory LH surge } & \multirow[b]{2}{*}{$\begin{array}{l}\text { Ovulation } \\
\text { after } \\
\text { peak of } \\
\text { LH surge } \\
\text { (hr) }\end{array}$} & \multicolumn{2}{|c|}{ Time from treatment to } \\
\hline & & & & $\begin{array}{c}\text { Time from } \\
\text { treatment } \\
\text { to peak } \\
\text { (hr) }\end{array}$ & $\begin{array}{l}\text { Peak value } \\
(\mathrm{ng} / \mathrm{m} l)\end{array}$ & & $\begin{array}{l}\text { Estrus } \\
(\mathrm{hr})\end{array}$ & $\begin{array}{l}\text { Ovulation } \\
\text { (hr) }\end{array}$ \\
\hline 137 & 1,000 & 0.60 & $1.25 \pm 0.20^{\mathrm{a})}$ & 36 & 35.00 & 36 & 36 & 72 \\
\hline 140 & 1,000 & 0.45 & $1.15 \pm 0.19$ & 34 & 23.50 & 27 & 42 & 72 \\
\hline 145 & 1,000 & 0.60 & $1.16 \pm 0.25$ & ND & ND & ND & NO & 84 \\
\hline 146 & 1,000 & 0.65 & $1.54 \pm 0.17$ & 36 & 35.00 & 36 & 36 & 72 \\
\hline $137^{*}$ & 2,000 & 0.65 & $1.35 \pm 0.17$ & 39 & 34.00 & 33 & 36 & 72 \\
\hline Overa & mean & $0.59 \pm 0.08^{\mathrm{b})}$ & $1.27 \pm 0.23^{c)}$ & $39.0 \pm 4.2$ & $31.88 \pm 5.60^{d)}$ & $33.0 \pm 4.2$ & $37.5 \pm 3.0$ & $74.4 \pm 5.4$ \\
\hline
\end{tabular}

1) The value just before the treatment.

2) Mean value from the treatment to $\mathrm{LH}$ surge.

a) Mean $\pm \mathrm{SD}$.

ND: Not determined.

NO: No occurred.

* Treated again 153 days after the preceding PMSG treatment.

$\mathrm{b}, \mathrm{c}, \mathrm{d})$ Significant difference $(\mathrm{P}<0.01)$ was detected between $\mathrm{b}$ and $\mathrm{c}$, and $\mathrm{c}$ and $\mathrm{d}$, respectively.

\section{DISCUSSION}

hCG induced ovulation without the ovulatory LH surge about $36 \mathrm{hr}$ after treatment in ovarian quiescent cattle was demonstrated. It is generally accepted that $\mathrm{LH}$ is the main ovulatory hormone $[15,18]$. LHRH-A caused LH release which reached peak $2 \mathrm{hr}$ after treatment in ovarian quiescent heifer [9]. Both LH-RH-A and hCG induced ovulation about $36 \mathrm{hr}$ after the treatments $[7,8]$. These understanding and 


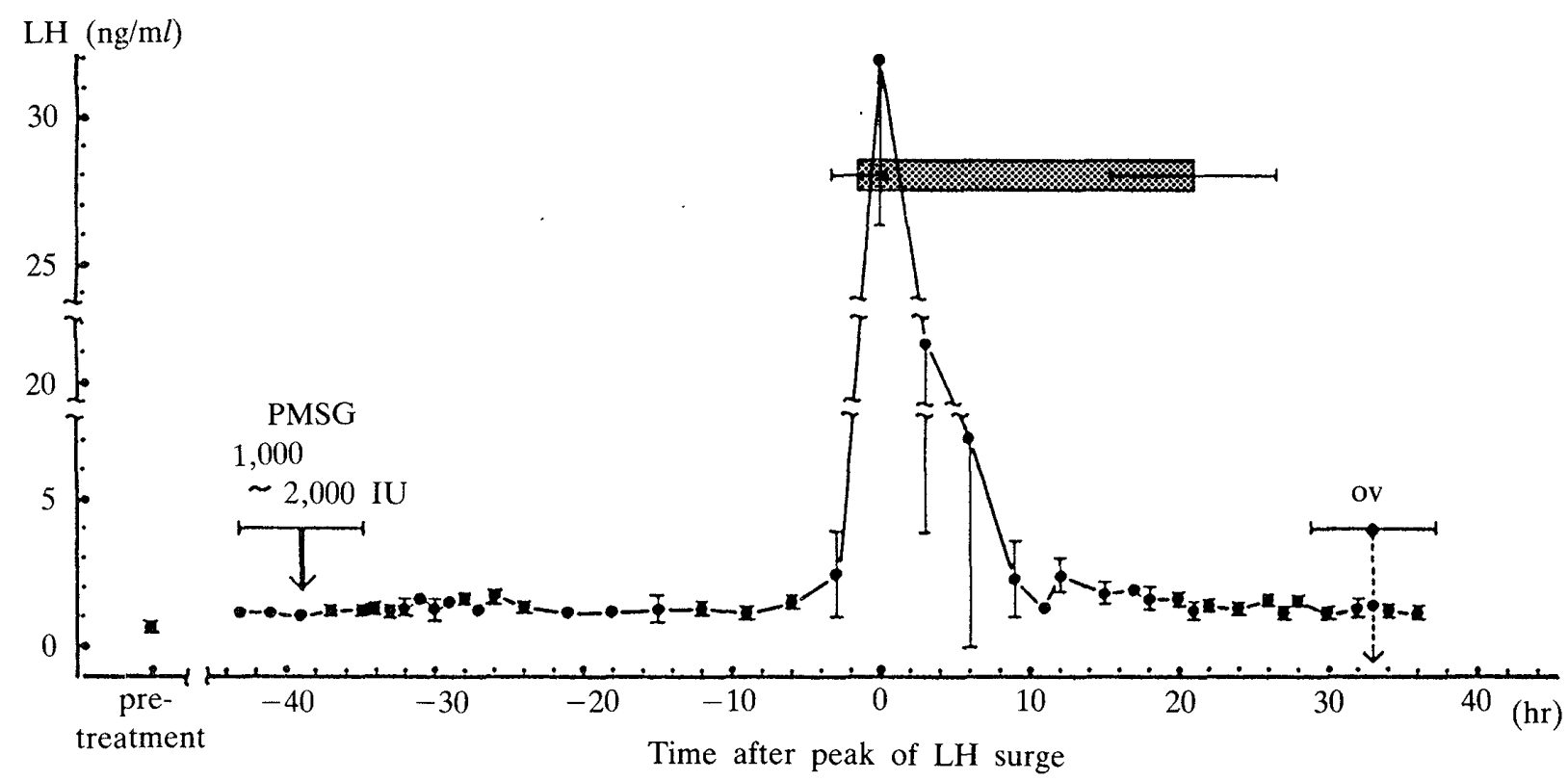

Fig. 2. Change of blood LH level following PMSG treatment in ovarian quiescent cattle (Nos. 137, 140, $\left.146,137^{*} ; n=4\right)$. $\Phi$ : Mean $\pm \mathrm{SD}$, Estrus, ov: Ovulation.

findings indicate that if hCG caused ovulation by provoking the ovulatory LH surge, the LH surge should occur within several hr after the treatment same as after the LHRH-A. But the LH surge did not occur after the hCG treatment. Further, as previously reported [8], blood estradiol-17 $\beta\left(\mathrm{E}_{2}\right)$ level did not show obvious increase from treatment to ovulation. These facts indicate that hCG acts directly on follicle to induce ovulation. Dobson and Fitzpatrick [1] showed that hCG caused ovulation without inducing the endogenous ovulatory $\mathrm{LH}$ surge about $22 \mathrm{hr}$ after treatment in cycling cows. Sasamoto et al. [16] also reported that hCG induced ovulation within $18 \mathrm{hr}$ after treatment but the ovulatory LH surge did not occur during the period in diestrus rat. Present result agreed with those ones.

LH level became slightly higher after hCG treatment in overall mean of Experiment A-1, and in Experiment A-2. Posttreatment $\mathrm{LH}$ increase became conspicuous as the dosage increased. Two possibilities are suspected for the reason; one is hCG cross-reacts to bovine LH in the assay and another is hCG stimulates the $\mathrm{LH}$ release in low level. As to the former Dobson and Fitzpatrick [1] noticed hCG did not appreciably cross-react to bovine LH. In our assay hCG cross-reacted very slightly as 1 IU of hCG corresponded to $0.01-0.06 \mathrm{ng}$ of bovine $\mathrm{LH}$ in range of $0.1-100 \mathrm{IU}$ of hCG (unpublished data). When hCG treated is all absorbed into blood flow, the blood hCG concentration is calculated as much as 0.26 $\mathrm{IU} / \mathrm{m} l$ after treatment of $6,000 \mathrm{IU}$. Under the such low concentration of blood hCG the cross-reaction of hCG to $\mathrm{LH}$ could be negligible. So, the slight increase of $\mathrm{LH}$ after the treatment might come from hCG stimulating the $\mathrm{LH}$ release in low level. Supplementally, both the pre- and the posttreatment $\mathrm{LH}$ levels were different between Experiments A-1 and A-2. These differences might come from the different two lot of bovine LH were utilized in the LH assays of Experiment A-1 and Experiment A-2.

This experiment demonstrated that the ovulatory LH surge was induced about $39 \mathrm{hr}$ after PMSG treatment in ovarian quiescent cattle. Blood $\mathrm{E}_{2}$ level reached a peak on $2 \mathrm{nd}$ 
day after PMSG treatment [6] and the increased esrogen $(E)$ triggered the ovulatory $\mathrm{LH}$ surge under the low concentration of progesterone (P) $[11,15]$. These facts indicate that PMSG make follicle grow and secrete $E$ actively so that increased $E$ trigger the LH surge and ovulation occurred subsequently. Echternkamp [2] reported that PMSG caused $E_{2}$ peak and subsequent ovulatory $\mathrm{LH}$ surge about $60 \mathrm{hr}$ after the treatment in postpartum ovarian inactive beef cows. In perpubertal female rat, peaks of $E_{2}$ and ovulatory gonadotrophin surge occurred 42--54 hr and 52-61 hr after PMSG treatment, respectively, and ovulation took place $66 \mathrm{hr}$ or within $72 \mathrm{hr}$ after the treatment $[10,14,17,20,21]$. Present result agrees with those results. In present result the LH surge occurred earlier than in postpartum ovarian inactive beef cows [2] as described above. The earlier occurrence of LH surge may come from that in the cattle used follicles were already palpable and the follicles responded to PMSG and secreted $\mathrm{E}_{2}$ actively immediately after the treatment so that $E_{2}$ level reached the high in a short time.

LH level became slightly higher after the PMSG treatment and lasted the level until the ovulatory LH surge. Wettemann et al. [19] pointed out the similar increase after PMSG treatment in cows. They indicated that PMSG cross-reacted to LH in their radioimmunoassay and blood PMSG concentration $12 \mathrm{hr}$ after treatment with 2,000 IU was calculated to correspond to $3 \mathrm{ng} / \mathrm{m} l$ of LH. They considered the slight increase of LH after PMSG to come from the cross-reaction. The authors also noticed that PMSG cross-reacted to LH and 0.01, 0.1, 1, 10,100 and 1,000 IU of PMSG corresponded to about $0.07,0.4,1,2,7$, and 90 ng of bovine $\mathrm{LH}$, respectively, in this assay (unpublished data). When injected PMSG all absorbed into the blood flow, the blood PMSG concentration was calculated to
0.04-0.07 IU $/ \mathrm{m} l$ and considered to correspond to about $0.3-0.5 \mathrm{ng} / \mathrm{m} l$ of $\mathrm{LH}$. This cross-reaction of PMSG to LH may attribute to the increase of $\mathrm{LH}$, but the increase was not fully explained only by the crossreaction because some disparity is present between the post-treatment $\mathrm{LH}$ increase and the cross-reaction value. Therefore it is suspected that PMSG might stimulate the $\mathrm{LH}$ release in low level.

In 1 case the ovulatory LH surge could not be certified after the PMSG treatment. But $\mathrm{LH}$ level increased to about $3.1 \mathrm{ng} / \mathrm{m} l$ at 36 and $48 \mathrm{hr}$ after the treatment. The LH surge should be occurred between 36 and 48 hr after the treatment in this case.

ACKNOWLEDGEMENTS. We thank to Dr. H. Hatakeyama, Epidemiology Laboratory, National Institute of Animal Health, Tsukuba, Ibaraki for kind support of statistical analysis.

\section{REFERENCES}

1. Dobson, H. and Fitzpatrick, R. J. 1975. The effect of HCG or endogenous gonadotrophin on normal bovine follicular activity. J. Reprod. Fert. 43: 337-340.

2. Echternkamp, S. E. 1978. Stimulation of estrogen and luteinizing hormone secretion in postpartum beef cows. J. Anim. Sci. 47: 521-531.

3. Ford, S. P. and Stormshak, F. 1978. Bovine ovarian and pituitary response to PMS and GnRH administered during metestrus. J. Anim. Sci. 46: 1701-1706.

4. Hallford, D. M., Turman, E. J., Wettemann, R. P., and Pope, C. E. 1979. Endocrine and reproductive response of beef cows to PMSG. J. Anim. Sci. 49; 1030-1036.

5. Laing, J. A. 1970. Non-infectious abnormalities and disorders causing infertility in female animals. pp. 355-428. In: Fertility and Infertility in the Domestic Animals, 2nd ed. (Laing, J. A. ed.), Bailliere Tindall and Cassell, London.

6. Kamomae, H., Kaneda, Y., Domeki, I., Iwamura, S., Arai, T., Ogasa, A., and Nakahara, T. 1985. The effect of PMSG on ovarian function in ovarian quiescent heifers. Jpn. J. Vet. Sci. 50: 1221-1230.

7. Kamomae, H., Kaneda, Y., Domeki, I., and Nakahara, T. 1985. Ovarian changes and plasma 
progesterone and estradiol-17 $\beta$ levels in ovarian quiescent heifers after treatment with $\mathrm{LH}-\mathrm{RH}$ analogue. Jpn. J. Anim. Reprod. 31: 48-56 (in Japanese with English summary).

8. Kamomae, H., Kaneda, Y., Domeki, I., and Nakahara, T. 1986. Ovarian changes and plasma progesterone and estradiol-17 $\beta$ levels in ovarian quiescent heifers after treatment with hCG. Jpn. J. Anim. Reprod. 32: 13-23 (in Japanese with English summary).

9. Kamomae, H., Kaneda, Y., Domeki, I., and Nakahara, T. 1988. Effects of LH-RH analogue on LH release and ovarian function in ovarian quiescent heifers. Jpn. J. Vet. Sci. 50: 613-621.

10. Klawon, D. L., Sorrentino, S. Jr., and Schalch, D. S. 1971. Plasma luteinizing hormone dynamics in pregnant mare serum-induced ovulators as measured by radioimmunoassay: Influence of testosterone. Endocrinology 88: 1131-1135.

11. Morrow, D. A. 1986. Current Therapy in Theriogenology 2, W. B. Saunders, Philadelphia.

12. Nakahara, T., Domeki, I., and Yamauchi, M. 1970. Ovulatory response of quiescent ovary in beef cattle by injecting lower dose of human chorionic gonadotrophin. Jpn. J. Anim. Reprod. 16: 58-65 (in Japanese with English summary).

13. Niswender, G. D., Reichert, L. E. Jr., Midgley, A. R. Jr., and Nalbandov, A. V. 1969. Radioimmunoassay for bovine and ovine luteinizing hormone. Endocrinology 84: 1166-1173.

14. Parker, C. R. Jr., Costoff, A., Muldoon, T. G., and Mahesh, V. B. 1976. Actions of pregnant mare serum gonadotropin in the immature female rat: Correlative changes in blood steroids, gonad- otropins, and cytoplasmic estradiol receptors of the anterior pituitary and hypothalamus. Endocrinology 98: 129-138.

15. Roberts, S. J. 1986. Veterinary Obstetrics and Genital Disease (Theriogenology), 3rd ed. Edwards Brothers, Michigan.

16. Sasamoto, S., Harada, S., and Taya, K. 1977. Selective release of follicle-stimulating hormone during the period of ovulation induced by human chorionic gonadotrophin in dioestrus rats. $J$. Endocr. 75: 179-180.

17. Sasamoto, S. and Johke, T. 1975. FSH and LH release during the first ovulation period of immature rats pretreated with PMS. Biol. Reprod. 13: $195-202$.

18. Sherwood, O. D. and McShan, W. H. 1977. Gonadotropins. pp. 17-43. In: Reproduction in Domestic Animals, 3rd ed. (Cole, H. H. and Cupps, P. T. eds.), Academic Press, New York.

19. Wettemann, R. P., Beck, T. W., Turman, E. J., and Hintz, R. L. 1982. Endocrine response of postpartum anestrous beef cows to GnRH or PMSG. Theriogenology 18: 599-613.

20. Wilson, C. A., Horth, C. E., Endersby, C. A., and McDonald, P. G. 1974. Changes in plasma levels of oestradiol, progesterone and luteinizing hormone in immature rats treated with pregnant mare serum gonadotrophin. J. Endocr. 60: 293-304.

21. Yamamoto, M., Umezu, M., and Masaki, J. 1978. Effects of age on the changes of pituitary and serum gonadotrophin levels during PMSinduced ovulation in prepubertal rats. Tohoku $J$. Agricult. Res. 29: 70-78.

卵巣静止の牛における hCG 拉よび PMSG 処置後の血中 LH の推移と誘起排卵：加茂前秀夫*・金田義宏 ${ }^{1)}$. 百目鬼郁男 ${ }^{2)} \cdot$ 中原達夫 ${ }^{3)}$ (農林水産省家畜衛生試験場, ${ }^{1}$ 岩手大学農学部, ${ }^{2}$ 農林水産省畜産試験場, ${ }^{3}$ ) 東京農 業大学総合研究所, *現在, 農林水産省畜産試験場) 一一卵巣静止の牛13例に人絠毛性性腺刺激ホルモン ( $\mathrm{hGC}$ ) 750 6,000 IU，5例に妊馬血清性性腺刺激ホルモン（PMSG）1,000 2,000 IU をそれぞれ筋肉内に 1 回注射 し，末梢血液中の黄体形成ホルモン（LH）の推移および発情と排卵の状況を調べた. hCG 処置後，血中 LH は 処置時の值 $(0.2 \sim 0.6 \mathrm{ng} / \mathrm{m} l)$ より幾分增加 $(0.3 \sim 1.9 \mathrm{ng} / \mathrm{m} l)$ して排卵まで推移したが，排卯性 $\mathrm{LH}$ 放出はみ られなかった，排卵は処置後36時間前後に12例で誘起されたが，いずれも無発情排卵であった．PMSG 処置後， 血中 $\mathrm{LH}$ は処置時の值 $(0.6 \mathrm{ng} / \mathrm{ml})$ より幾分増加 $(1.3 \mathrm{ng} / \mathrm{m} l)$ して推移した後， 4 例において 39 時間前後に明 瞭な排卵性 $\mathrm{LH}$ 放出 $(32 \mathrm{ng} / \mathrm{m} l$ 前後）を示した．排卵は处置後74時間前後に全例で誘起された．誘起排卵に先 だって 4 例で発情が発現したが，排卵性 LH 放出が確認できなかった 1 例は鈍性発情であった。これらのことか ら, 卵巣静止の牛において，hCG は排卵性 LH 放出を惹起することなく排卵を起こすのに対し，PMSG は排卵 性 LH 放出を惹起することにより排卵を起こすことが明らかになった. 